\title{
LIVESTOCK SCIENCE
}

\section{Natural living - a precondition for animal welfare in organic farming}

\author{
Vonne Lund * \\ National Veterinary Institute, PO Box 8156 Dep., N-0033 Oslo, Norway
}

Received 1 April 2004; received in revised form 25 July 2005; accepted 3 August 2005

\begin{abstract}
This article discusses animal welfare in organic farming systems in relation to values and aims in organic farming. It sums up experiences from a 4-year interdisciplinary project. An important finding is that animal welfare is understood somewhat differently in organic farming from what is common in conventional agriculture. It is interpreted in terms of natural living, which includes the possibility to perform a natural behaviour, feed adapted to the animal's physiology and a natural environment. Some of the criticism of animal welfare in organic farming may stem from different understandings of what "welfare" actually means. However, although welfare is an important aim in organic farming, the overall concern is to develop sustainable farming systems. This causes some welfare dilemmas. For example, a healthy system does not automatically mean good welfare for the individual. Based on available literature the actual welfare situation in organic systems was scrutinized. Unfortunately little research has been done, but a careful conclusion was that animal health is as good or better than in conventional farming — with the exception of parasitic diseases. Organic farming systems have a "welfare potential", but organic farmers must deal with the dilemmas and take animal welfare issues seriously.
\end{abstract}

(C) 2005 Elsevier B.V. All rights reserved.

Keywords: Animal welfare; Ecocentric ethics; Natural behaviour; Organic farming; Organic animal husbandry

\section{Introduction}

Farm animals make important contributions to organic farming systems (Lund et al., 2004a) and animal agriculture is an integral part of most organic farms. The early organic farming movements were

\footnotetext{
* Tel.: +47 232163 67; fax: +4723216485.

E-mail address: vonne.lund@vetinst.no.
}

critical of industrialized animal husbandry. Not only were they concerned with the negative environmental impact of these systems but also with the welfare of the animals in them. The ambition was to develop more sustainable and environmentally friendly farming systems, but also systems allowing farm animals a better quality of life. Animal welfare has henceforth been a concern in organic farming (Niggli and Lockeretz, 1996; Boehncke, 1997; Roderick and Hovi, 1999, Lund et al., 2002). Animal welfare is included among 
the general principles for organic animal husbandry stated by the International Federation of Organic Agricultural Movements, IFOAM (the IFOAM Basic Standards are the most widely used organic standards worldwide):

"Organic livestock husbandry is based on the harmonious relationship between land, plants and livestock, respect for the physiological and behavioural needs of livestock and the feeding of good-quality organically grown feedstuffs (IFOAM, 2002)".

Welfare concerns are also included in standards dealing with transport and slaughter (IFOAM, 2002).

In spite of this, the welfare status of animals in organic farming has been debated. In several countries critics have questioned whether organic production methods imply good animal welfare (e.g., Danish Ethical Council concerning Animals, 1995; Jensen, 1999; FAWC, 2001). Also, the question has been raised within the organic movement whether concern for animal welfare really should be part of organic farming aims. In England, for example, it has been argued that organic farming should not be an animal welfare scheme (Hovi, oral presentation at the 14th IFOAM Organic World Congress, August 21-24, 2002, Victoria, Canada). Consumers, on the other hand, generally appreciate the organic way of raising animals and believe animal welfare is better in organic than in conventional (non-organic) farming (e.g., Holmberg, 1999; Danish Ministry of Food Agriculture and Fisheries, 1999; Harper and Henson, 2001).

The debate raises some interesting questions regarding principles of livestock production and animal welfare in organic farming. The first question is: is there a specific "organic" understanding of the animal welfare concept? An equally important question is whether or not animal welfare should be of special concern in organic farming - can such aims be grounded in any underlying philosophy? If so, other questions arise: What kind of ethics should apply to the human-animal relation in organic farming, and what practical consequences would this imply for livestock production? Another relevant question is if the critics are right when arguing that animal welfare in organic systems is not acceptable.

These questions were studied in an interdisciplinary 4-year project at the Swedish University of Agricultural Sciences. The values inherent to organic farming were scrutinized in relation to animal welfare both in theory (through literature studies; Lund and Röcklinsberg, 2001; Lund et al., 2004a) and through two studies of Swedish organic livestock farmers (Lund et al., 2002, 2004b). Finally, animal welfare among organic animals was scrutinized as it appeared in scientific studies (Lund and Algers, 2003). This paper discusses and makes some overall conclusions from the project, regarding how animal welfare is understood in organic farming "ideology" in relation to the values and aims in organic farming.

\section{Methods}

The departure point for the present paper was achieved from the following studies: In one study the organic standards, in particular the IFOAM Basic Standards (2000), were used together with relevant literature to analyze basic values in organic animal husbandry. These were then related to ethical theory (Lund and Röcklinsberg, 2001). The results from this theoretical analysis were compared with attitudes and beliefs among organic farmers in two studies of Swedish organic livestock farmers' view of animal welfare related issues. The first of these was based on focused, semi-structured interviews (Lund et al., 2002). It was followed by a questionnaire study, of which the results were analyzed through principal components analysis (exploratory factor analysis) and multiple regression models. A literature study was undertaken to investigate how well the organic aims regarding animal welfare match reality (Lund and Algers, 2003). Another part of the project discussed how to ethically handle animal welfare dilemmas and ethical issues in organic animal husbandry (Lund et al., 2004a). One may note that biodynamic farming, which counts among the organic farming movements and represents a distinct philosophy of life, was not included in the project.

\section{Results}

\subsection{Animal welfare from an organic perspective}

Opinions diverge regarding what constitutes a good quality of life for animals and what animal 
welfare means in practice. For example, is it enough that a hen is in good health or should she also be able to dustbathe and perch in order to have good welfare? Accordingly the definition of "animal welfare" has been widely debated among philosophers and scientists. In this project the underlying values in organic farming were taken as departure point for defining the concept of animal welfare in organic farming, and the result was then compared with the attitudes among organic farmers.

Organic farming puts emphasis on the interconnectedness among all living beings and between them and their environment. Nature is perceived as providing good models for human action, and humans should cooperate with nature (Rolston, 1988, pp. 230-232; Callicott, 1989, pp. 117-127). Interventions in nature's processes should be kept to a minimum (DARCOF, 2000 , p. 10). This is mirrored in the IFOAM Basic Standards (2000), which state that organic farming systems are "directed towards enhancing natural life cycles rather than suppressing nature". Applying this thinking to animal welfare, "living a natural life" becomes essential: a good quality of life then means that the animal should have the possibility to perform a natural behaviour (as discussed by Algers, 1992), get feed suitable to its physiology (e.g., ruminant diets should not be based on grain and concentrates but on fibrous plants) and live in an environment as similar as possible to the biotope natural to the species. The exact meaning of "natural living" can of course be debated. A useful departure point for implementing the concept can be a definition suggested by Fraser et al. (1997): "the possibility to develop according to the animal's encoded genetic nature".

The organic interpretation of the animal welfare concept can be compared with some common approaches to the concept:

The affective states approach, claiming that only animal feelings, such as suffering, pain or pleasure, should count when welfare status is evaluated (e.g., Dawkins, 1988; Duncan, 1993).

The biological functioning approach, arguing that good quality of life is when the animal's biological systems are functioning in a normal or satisfactory manner or when the animal can cope with its situation (e.g., Broom, 1991; McGlone, 1993).

The natural living approach, proposing that an animal's welfare depends on the possibility of expres- sing its natural behaviour (Webster et al., 1986) and living a "natural" life according to its genetically encoded nature or "telos" (Rollin, 1993).

The above positions partly overlap, to a degree depending on the specific interpretation of each position (Fig. 1). The organic interpretation of animal welfare is close to the last of these three positions; hence, it is not unique to the organic movement.

The understanding of animal welfare in terms of natural living was found among the Swedish organic farmers, especially among the pioneers (Lund et al., 2002, 2004b). This confirms the theoretical analysis. In a questionnaire study (Lund et al., 2004b), items related to "classical" animal ethics, dealing with dignity, intrinsic value and rights, and items related to the importance of natural living came out as two separate concepts. The natural living approach was much more central to organic farmers than the animal ethics concept. The latter has always been embraced by animal protection movements but has not to the same extent been inherent in the organic movement, and this also was true for the organic farmers that were studied. The earlier conversion to organic farming had taken place,

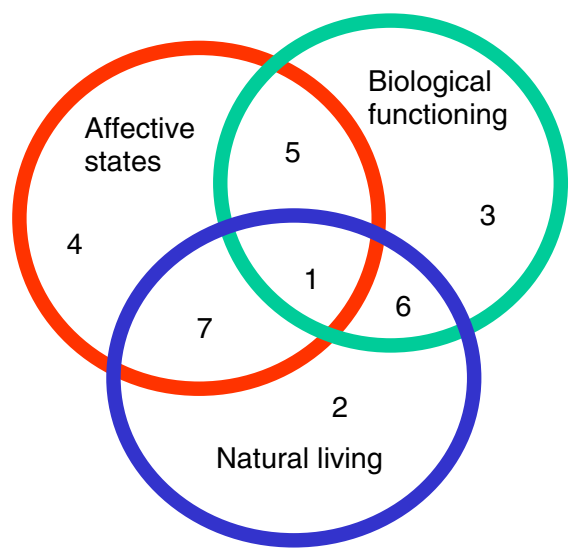

Fig. 1. Three definitions of the animal welfare concept. Circles represent: the affective states approach, the biological functioning approach and the natural living approach. Figure in a circle indicate examples of stress or ailments that could be considered acceptable by the particular welfare definition. 1. Pigs outdoors in summer, nice weather. 2. Pigs with subclinical parasite infections, outdoors in bad weather. 3. Sows weaning 25 piglets per year. 4 . Pigs fed antistress substances, such as amperozide, to compensate for bad environment. 5. Pigs fed low dosage antibiotics to compensate for bad environment. 6. Pigs outdoors, exposed to predators (i.e., fox occasionally sneaking around the field). 7. Pigs with subclinical parasite infections, outdoors in nice weather. 
the more likely the farmer was to regard natural living as important. The emphasis on natural living was also striking in the interview study. The conclusion is that in organic farming natural living is considered a precondition for animal welfare, and it has a value per se.

\subsection{Focus on sustainability}

Although animal welfare always has been an issue of concern among organic farmers, and many consumers associate organic farming with enhanced animal welfare, the study indicated that the organic movement's primary goals deal with ecological sustainability rather than animal welfare. For example, IFOAM has defined organic agriculture as "a process which develops a viable and sustainable agroecosystem" (IFOAM, 2000). Out of 15 general principles stated in the IFOAM Basic Standards (2002), only one deals directly with animal welfare (Table 1). This was also mirrored in the Swedish questionnaire study, in which the number one reason why farmers had converted their livestock to organic production was that this "represents a more holistic approach to farming". The item ranked second was that organic farming is "More future oriented". "More environmentally friendly" was their third choice while "More animal welfare friendly" only came out as number four in the total ranking (Lund et al., 2004b).

However, this does not mean that organic farmers feel animal welfare is unimportant- the literature study indicated the opposite, and this was confirmed

Table 1

The IFOAM principles in which animals are explicitly mentioned

The principle aims of organic production and processing

Organic Production and Processing is based on a number of principles and ideas. All are important and this list does not seek to establish any priority of importance. The principles include:

- To work compatibly with natural cycles and living systems through the soil, plants and animals in the entire production system.

- To create a harmonious balance between crop production and animal husbandry.

- To provide living conditions that allow animals to express the basic aspects of their innate behaviour.

Animals are mentioned in 3 out of a total of 15 stated principles (IFOAM Basic Standards for Organic Production and Processing, 2002, p. 13). in the questionnaire study. The two items scoring the highest means of all in the questionnaire study both were about animal welfare (Lund et al., 2004b). Farmers strongly agreed with the statements "Farm animals have the right to feel well (physically and mentally)" and "Farm animals should be allowed to live a dignified life"- -both got an average of 6.69 on a scale of 7 , with a standard deviation of 0.71 and 0.65 respectively. The questionnaire was mailed to $56,5 \%$ of Swedish farmers with animal husbandry and the response rate was $75,6 \%$.

It may be in place here to underline the importance of differentiating between the organic movement, which holds the ideals and visions of organic farming, and organic farmers in general (Lockeretz and Lund, 2003). The latter may not share the basic values and beliefs in organic farming but have chosen to farm organically for other reasons, for example that it is economically feasible. Both the interview and the questionnaire study indicated that Swedish organic livestock farmers can be divided into two groups, representing two subpopulations of farmers with different attitudes and behavioural dispositions. One group generally had a very positive attitude towards organic farming, considering it more of a life style than merely a form for production. This group was called "the pioneers", since the values and beliefs in the group were similar to those found in the early organic movement. There also was a correlation between this attitude and early conversion of the farm to organic farming. The other group comprised "the entrepreneurs". The farmers in this group generally voiced more criticism towards organic farming and considered making money and new challenges more important (Lund et al., 2004b). The two groups also had different views on animal welfare: while the pioneers saw "natural living" as important for animal welfare, the entrepreneurs were more accepting towards intrusive techniques like castration and embryo transfer.

\subsection{Underlying philosophy and ethics}

The question whether animal welfare should be of concern in organic farming is closely connected to the question what kind of ethical principles that should apply to the human-animal relation in organic farming. The values of the underlying philosophy are expressed in the ethical guidelines for the relation, 
thus, it is important to clarify the underlying philosophy of organic farming.

A major problem when trying to do this is that the "organic philosophy" until now has not been articulated and made explicit. Work to further articulate the principles of organic farming has now been started by IFOAM (see www.organic-revision.org and http:// ecowiki.org/IfoamPrinciples/HomePage). The organic standards, for example, serve many purposes and are often a compromise between the ideals and the practical or political reality (Lockeretz and Lund, 2003). However, it is clear that organic farming is not just any mishmash of ideas that early organic farmers happened to like, but it is underpinned by a value system coherent enough to be related to ethical theories (Lund, 2002; Verhoog et al., 2004). In this project ecocentric ethics was suggested as a suitable position for organic farming, based on the findings in the different subprojects (Lund and Röcklinsberg, 2001; Lund et al., 2004a). Ethical theories dealing with questions regarding human-animal and humannature relations are often roughly divided into four categories (Leopold, 1949; Singer, 1981; Stenmark, 2002), although the idea of an evolution of ethics has been discussed by several philosophers before Leopold and Singer, e.g., Albert Schweizer, Thomas Huxley and Peter Kropotkin, as well as by Charles Darwin (Sörlin, 1991, p. 177):

- Anthropocentrism is the view that humans, and only these, have direct moral status.

- Sentientism is the view that all sentient beings, and only these, have direct moral status.

- Biocentrism is the view that all living beings, and only these, have direct moral status.

- Ecocentrism is the view that also species, ecosystems and other relevant features in nature have direct moral status.

(See also Fig. 2.) Here the use of these terms relates to the theory's focus on moral concern.

The choice of ecocentric ethics is supported by that it grew out of the same kind of concerns as organic farming and largely responds to the same kind of issues, in particular the environmental concerns. Ecocentric ethics also focuses on systems rather than parts and aims to consider issues in its large context (Stenmark, 2002). The latter clearly

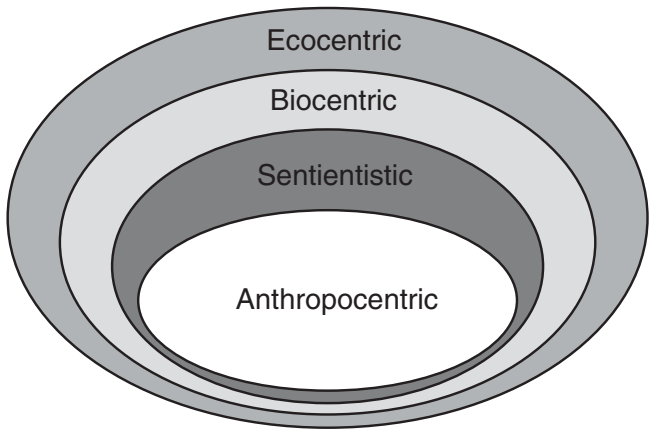

Fig. 2. The four main categories for ethical theories dealing with questions regarding human-animal and human-nature relations: anthropocentric, sentientistic, biocentric and ecocentric. In this paper the use of these terms relates to the theory's focus on moral concern.

showed in the interview study where the "pioneers" consistently discussed issues from this broad perspective, trying to pay attention both to history as well as the future (e.g., in terms of the needs of future generations) and considering local consequences in a global perspective (Lund et al., 2002). Thus, ecocentric ethics reflect that sustainability and establishment of sustainable systems are the main concern of organic farming.

However, applying ecocentric theories to agriculture is not unproblematic from a philosophical point of view, since these theories usually deal with human actions in relation to wild nature, and they expound a preservationist ethic that countenances the intrinsic worth of "untamed nature" (e.g., Leopold, 1949). Organic agriculture is consistent with the spirit of ecocentric ethics although it is not preservationist in the "classical" ecocentric sense, since it also is committed to promote development — but of a kind that need not be antithetical to ecocentric ideals. Biocentric ethics could be considered an alternative, but these theories focus on the individual organisms, whose well-being is something to be realized as an end in itself (Taylor, 1981). Usually this is interpreted so that killing of animals is not morally permissible, which makes the view incompatible with organic agriculture: livestock is essential for sustainable agroecological systems, and slaughter of animals is a necessity (Lund et al., 2004a). According to ecocentric theories, killing of animals is a moral problem only if they belong to a species threatened by extinction (Stenmark, 2002, p. 82). Of the choices at hand 
ecocentric ethics is the alternative best complying with the spirit of organic farming.

\section{Discussion}

The organic understanding of the animal welfare concept, and the philosophy underlying organic farming, bring about some practical consequences for livestock production and also some dilemmas.

\subsection{The ethical foundation for welfare concerns}

The organic aim to create sustainable agroecosystems does not directly motivate far-reaching animal welfare concerns, neither does ecocentric ethics provide an obvious basis for animal ethics. This lack of undisputable guidelines for human obligations towards animals may be one reason why the development of organic standards and the organic animal production has been lagging behind that of organic plant production (Lund, 2002). The organic focus on systems is problematic, since animal welfare deals with the well-being of the individual. The question whether welfare concerns can be argued from an ecocentric position in fact caused an agitated philosophical debate among ecocentric ethicists and animal welfare advocates (see Hargrove, 1992, for a review). However, it is possible to argue for animal welfare concerns also from an ecocentric position. For example, there are forms of ecocentrism that allow consideration of both the ecosystem and the individuals. Their relative importance depends on whether a strong or weak form of ecocentrism is chosen (Stenmark, 2002). Strong ecocentrism is the view that both ecological wholes (such as species, ecosystems, the land or the biotic community) and the individuals (such as humans and animals) making up these wholes have a value in themselves, but as a rule the ecological wholes have a higher value than individuals (Stenmark, 2000, pp. 85-91). Alternatively a similar definition can be made from a consequentialist ethics, focusing only on the consequences and not dealing with intrinsic value. Weak ecocentrism assigns a higher value to, or more consideration of, individuals and in particular humans. The latter view allows animal welfare concerns. Another argument for animal welfare concerns within an ecocentric framework is based on the fact that farm animals have been part of the human mixed community for thousands of years. Therefore they also should be included in the duties humans have to members of the human community (Callicott, 1989, pp. 49-59). Callicott is by no means the only one suggesting the mixed community as a basis for the moral standing of animals. The most wellknown advocate of this approach is probably Mary Midgley (1983). In this project a claim for farm animal welfare was suggested based on their role as necessary, functional partners in sustainable agroecosystems (Lund et al., 2004a). An ethical contract between the farmer and the animals could grant animal welfare, making it as a necessary condition for humans benefiting from animals. There are also other approaches opening for animal welfare concerns. Næss argues that all living beings relate to one another, both on a deep mystic level and in the ecosystem (Næss, 1985, 1989). This urges humans to handle animals with great respect. Similar thoughts can be found with the German philosopher MeyerAbich (1997, p. 295). Verhoog et al. (2003) distinguish three different approaches to organic farming: the simplistic "no chemicals" approach, the agroecological approach focusing on well-functioning agroecological systems, and the integrity approach. This last approach "is the result of an inner process of involvement with the way of being of natural entities" through which the farmer develops respect for the wholeness, harmony, or identity of each living entity.

\subsection{Consequences of an alternative understanding of animal welfare}

In organic farming allowing animals a natural life is considered a good in itself and a precondition for a good life. This means that even some negative experiences for the individual may be tolerated. To an extent, such experiences are perceived as a natural part of life that can never be completely deleted from an individual animal's spectrum of experiences (Alrøe et al., 2001; Lund and Röcklinsberg, 2001). This does not mean that such experiences are not negative for the individual as they happen, but rather that they are viewed as an important part of the functional feedback system connecting individual behaviour and the sur- 
rounding world. This interpretation of the animal welfare concept may be one reason why organic farming has been criticized. For example, a pig outdoors in bad weather with a subclinical parasite infection fulfil many criteria for having a natural life, but may not be considered as having good welfare by a veterinarian, who is likely to interpret the concept of animal welfare in terms of physical health rather than natural living (see Fig. 1). The consumers' understanding of animal welfare on the other hand seems to be closer to the natural living approach (Szatek, 2001; Te Velde et al., 2002): they are delighted to see outdoor pigs or calves suckling their mothers. A Dutch study of farmers' and consumers' perceptions of animal welfare found a big difference between the two groups (Te Velde et al., 2002). While farmers mainly interpreted animal welfare in terms of health and production (the biological functioning approach), consumers interpreted it in terms of freedom to move and fulfil natural desires. Thus, the understanding of animal welfare among consumers seems to be similar to that of the organic movement, while it differs both from that of traditional animal welfare organizations and the one frequently found among those educated in conventional agriculture. Interestingly, the questionnaire study showed that agricultural education was conversely related to the attitude that natural living is important (Lund et al., 2004b).

It is important to remember that the one interpretation of the welfare concept is not more "correct" than the other, since the discussion concerns values rather than facts. A conclusion is that the organic movement needs to be explicit about their understanding of the animal welfare concept when relating to others concerned with the issue. Also, extension officers, veterinarians and other "support staff" must make efforts to understand the organic philosophy even though it may differ from their own values. The strong relationship between world view and production practices (Allen and Bernhardt, 1995; Kaltoft, 1997) makes insights of the organic approach a prerequisite for relevant problem solving in organic systems (Kaltoft, 1997; Egri, 1999; Vaarst and Bennedsgaard, 2001). The organic farmer's advisors must be aware of that some solutions, although obvious in conventional agriculture, may not be available to organic farmers because they do not agree with underlying values.

\subsection{Animal welfare dilemmas}

The ecocentric approach is the cause of several dilemmas in organic farming. The relationship between a well-functioning system and individual welfare is not as straight-forward as anticipated by organic pioneers who, having this approach, may tend to overlook negative system effects on the individual - organic feed and a natural life is not enough to guarantee a good quality of life. For example, Swedish slaughterhouses have had some problems with organic animals being too thin, making the meat difficult to sell, especially in the early days of organic farming when organic production methods were not fully developed (Alarik, pers. comm.; Anon., 1999).

The priority of system health over individual welfare is manifested in a general ban on routine use of antibiotics and anthelmintics and longer withdrawal times. Organic farmers have thus been accused of avoiding necessary treatments, jeopardizing animal welfare (e.g., Anon., 1998; Beck-Friis, 2002; Andrews, 1991; Vaarst et al., 2001). However, it is against the ecocentric view to solve problems with intrusive techniques of this kind. Instead the objective is "to do everything possible to ensure that all living organisms the farmer works with, from micro-organisms to plants and animals, become allies" (Danish Ministry of Food Agriculture and Fisheries, 1999), and pathogens should not be eradicated but controlled. Solutions should co-operate with or resemble nature. For example, disease should be prevented through enhancement of the immune defence, selection of appropriate breeds or the use of alternative methods like herbal medicine or homeopathy (IFOAM, 2000; Council Regulation, 1999) or health plans based on the herd situation (NAHWOA, 2002; Hovi et al., 2003), and parasite infections through rotational grazing. When disease occurs the cause must be identified and measures taken to prevent future outbreaks, for example through changes in management practices or breeding. Other arguments against the use of synthetic substances that may pass unaltered through the treated animal are that they affect ecosystem health and the micro flora and fauna in the dung and maybe further in the ecosystem (Strong, 1993; McCracken, 1993), and the practice can be considered unsustainable because microorganisms are likely to develop resistance (SOU, 
1997; Waller, 1997; Hugoson and Wallén, 2000). In addition there is the risk of getting residues in food (SOU, 1997).

Although organic farmers have ideological as well as economic reasons (premiums for organic production can be lost) not to use antibiotics, the criticism was not confirmed by the literature study (Lund and Algers, 2003). Somatic cell counts or incidences of mastitis were not higher in organic herds (Vaarst and Bennedsgaard, 2001; Vaarst et al., 2001; Hardeng and Edge, 2001; Hamilton et al., 2002; Toledo et al., 2002). Other methods seemed to be used instead, for example frequent milking of affected udder quarters and massage (Vaarst et al., 2001; Hamilton et al., 2002), or antibiotics were used to treat the more severe cases (Weller and Bowling, 2000). Thus, the problem may be overestimated, although practices may differ among countries.

Another major dilemma caused by the ecocentric approach is the conflict between the natural living principle versus individual welfare interpreted in terms of "prevention of suffering" or "promotion of health". In organic farming a more natural environment is preferred over a well-controlled environment where the animal is protected from dangers but less able to have a natural life. Hence free ranging animals have become a symbol of organic farming in spite of implying increased risks of predator and parasite exposure and related diseases, e.g., Coccidiosis and Ascarid infections in poultry (Heuer et al., 2001; Permin et al., 1999), piroplasmosis and severe gnat problems in cattle (Hammarberg, 2001), and trichinosis and Erysipelas infections (Kugelberg et al., 2001) in pigs. Likewise, free-range systems are stipulated for poultry although outbreaks of feather pecking or cannibalism cause greater damage in large groups compared to among caged hens (Bilcik and Keeling, 1999). However, the foraging opportunities in free range systems should reduce the risk of outbreaks (Johnsen et al., 1998; Wechsler and Huber-Eicher, 1998). A further example is the organic preference for natural mating, even though artificial insemination programs are necessary to improve disease resistance and longevity.

A dilemma which has been accentuated with the outbreak of diseases such as the avian flu is the conflict between natural living including free range practices, and the risk of transfer of zoonotic diseases from wildlife to farm animals or among domestic free range herds, threatening human health.

Improved management, breeding and system development can overcome many of the problems caused by the ecocentric approach in organic farming, but, as already pointed out the problems also reflect basic differences in underlying values resulting in other priorities.

\subsection{Research regarding animal welfare in organic systems}

It is a relevant question to ask what the welfare situation looks like in reality. Unfortunately there is limited scientifically based knowledge about animal welfare in organic herds. A literature review on organic animal health and welfare found only 22 peer-reviewed articles (plus two overviews). All were focusing on clinical health, in spite of the organic emphasis on natural living (Lund and Algers, 2003). The papers were mainly dealing with dairy production and parasitology and very few dealt with pigs and poultry where the biggest differences in housing and management are to be found compared to conventional farming. The overall tendency in the reviewed papers was that health in organic herds was the same as or better than in conventional herds, with the exception of parasite-related diseases which were more frequent in organic farming. This is supported by other surveys (Hovi et al., 2003). No study found more overall health problems in organic herds than in conventional herds. However, all parasitological studies showed a higher prevalence of parasites in organic herds. This was true for pigs (Carstensen et al., 2002), poultry (Permin et al., 1999), sheep (Lindqvist et al., 2001), and probably also dairy cattle (Svensson et al., 2000; Hansson et al., 2000).

Apparently the control of internal as well as external parasites is an area where organic farming has not yet managed to develop good alternatives to conventional treatments. The animal welfare effects of these parasitic infestations are difficult to judge, however, at least for pigs and poultry (Thamsborg, pers. comm.). However, parasite infestation must be regarded as a risk factor for animal welfare.

Unfortunately the available literature does not allow any conclusions regarding overall welfare in organic systems. A very cautious conclusion regarding 
animal health is that there is a higher prevalence of parasites in organic herds, but overall health tends to be the same as or maybe better in organic farming as compared to conventional.

\subsection{The potential of organic farming in relation to welfare}

When discussing animal welfare in organic farming, it should be kept in mind that organic animal husbandry is still under development and that research efforts promoting this development so far have been quite limited. Therefore not only the current situation is of interest, but also the potential of these systems should be considered. The organic standards have a substantial "welfare potential". Until now they have generally been more far-reaching than the animal welfare legislation in most countries and also more detailed, including requirements regarding environmental enrichment and access to pasture. Animals that get to live in stimulating environments (which usually applies to free range conditions) where they can behave naturally generally have better welfare than animals kept in barren environments (as shown in different studies, e.g., Appleby and Hughes, 1991; de Jonge et al., 1996; de Passillé, 2001; Wemesfelder and Birke, 1997). Thus, some welfare problems common to conventional farming do not appear at all or very seldom in organic animal husbandry. Problems related to abnormal animal behaviour (such as tail biting in pigs), extreme production levels, or feeding regimens not adapted to the biology of the animals (such as BSE) are less likely to be found, as are diseases related to crowded or poorly ventilated indoor conditions or mixing of stock from various sources, for example several infectious diseases and diseases in the respiratory system (see also Sundrum, 2001).

However, any production system has inherent problems and the alternative approach in the organic philosophy and standards invites a particular spectrum of diseases. Good management can bring down parasitic infections which seem the biggest health challenge (Dimander et al., 2000; Höglund et al., 2001; Carstensen et al., 2002), and there is a cautious optimism regarding future possibilities for coping with parasites in ways complying with the organic standards (Niezen et al., 1996; Thamsborg et al., 1999).
This optimism is supported by that conventional farming has an interest in finding alternatives to chemical treatments because of increasing problems with resistant parasites (e.g., Barger, 1997; Gray, 1997; Waller, 1999).

Issues that need research include how to draw up organic standards with regard to animal welfare and how to evaluate animal welfare on farms, for control or to identify problem areas. Future research efforts should be directed towards areas such as diseases related to loose housing and free range production, longer withdrawal times and restrictions on medicine use, and feeding principles that may affect animal health and welfare, e.g., the ban on synthetic amino acids and vitamins as feed additives (the latter only for ruminants). The conversion period is another problematic area since the farmer must learn and adjust to new practices (Vaarst et al., 2001).

The alternative outlook of organic farming may also open up new ways of thinking about animal welfare problems and thereby of finding solutions. The systemic view advocated in organic farming makes it relevant to discuss welfare in relation to different systemic levels. It becomes relevant to see individual welfare in relation to herd or farm level and even to the agroecosystem (Faye et al., 1999) or the ecosystem, since the overall health of these systems is essential for the health and welfare of the individual animal. To include all these levels in one welfare concept would be to extend it far beyond its common use, and it would be almost impossible to make such a broad concept operational. But when focus no longer is exclusively on the individual, systemic solutions also become feasible (Alrøe et al., 2001). This includes changes in breeding goals and management (herd level), farm structure (farm level) or even consumption patterns (societal level). Thus, the EU regulation for organic farming mentions "selection of appropriate breeds" as the premier principle for disease prevention, and "an appropriate density of livestock" is another principle (Council Regulation, 1999, 5.1 [a] and [d]). This is not to say that these "systemic" solutions are not also available in more individual-focused approaches, but they may not be as obvious or first-hand as in a systemic approach.

The optimal solution is when animal welfare can be integrated as part of the production system, thus benefiting both the animal and the system. An exam- 
ple is when the innate behavioural need of rooting in pigs (which is considered a problem in the pig industry) is utilized for useful work on the farm, for example tillage of fields or ground preparation in forestry (Andresen, 2000).

To realize the animal welfare potential organic farmers must take animal welfare issues seriously and recognize and discuss the dilemmas and challenges at hand.

\section{Conclusions}

Organic farming is substantially based in ecocentric ethics, and the overall goal is to create sustainable agroecosystems. However, animal welfare has from the start been an important goal and animal welfare concerns in organic farming can be supported by the underlying philosophy. Thus, animal welfare can be a concern in organic farming also henceforth.

In organic farming the animal welfare concept is understood in terms of natural living, which includes the possibility for the animal of performing a natural behaviour, getting feed adapted to its physiology and living in an environment similar to the biotope which the animal is evolutionary adapted to. This understanding differs somewhat from how animal welfare usually is understood in conventional farming and the divergence may give rise to some of the criticism which has claimed that animal welfare in organic systems is poor. In this debate it is important to recognize differences in underlying values and their consequences for priorities and actions. In organic farming natural living is considered a precondition for welfare and it has a value per se. This should be taken as a departure point when solutions are sought to various problems in organic animal husbandry. Thus it is important that the organic movement communicates its understanding of animal welfare in order to make way for more constructive discussions with the surrounding world, including extension workers and veterinarians.

There is a potential in organic farming to create systems that give farm animals good welfare, and current research does not contradict this. However, there are some dilemmas caused by the underlying philosophy, and these must be recognized and discussed so that solutions can be found which promote animal welfare within the given framework. At the same time, the organic approach can open up for new ways of thinking and for innovative solutions. Organic farmers must take animal welfare issues seriously.

\section{Acknowledgements}

The research was financed by a grant from the Swedish Council for Forestry and Agricultural Research and performed at the Department of Animal Environment and Health, Swedish University of Agricultural Sciences. This article was written at the National Veterinary Institute in Norway.

\section{References}

Algers, B., 1992. Natürliches Verhalten-ein natürlicher Begriff (Natural behaviour - a natural concept). Berl. Münch. Tierärtzl. Wochenschr. 105, 372-374.

Allen, J.C., Bernhardt, K., 1995. Farming practices and adherence to an alternative-conventional paradigm. Rural Sociol. 60, 297-309.

Alrøe, H.F., Vaarst, M., Kristensen, E.S., 2001. Does organic farming face distinctive livestock welfare issues?-A conceptual analysis. J. Agric. Environ. Ethics 14, 275-299.

Andresen, N., 2000. The foraging pig-Resource utilisation, interaction, performance and behaviour of pigs in cropping systems. Dissertation. Agraria 227, Acta Univ. Agr. Sueciae, Uppsala. $40 \mathrm{pp}$.

Andrews, T., 1991. Suffering animals in a green landscape? Dairy Farmer 38, 26-28.

Anon., 1998. Editorial. Dan. Vet.tidsskr. 81, 337.

Anon., 1999. Slaktkropparnas kvalitet i ekologisk uppfödning 1999. [The quality of organic carcasses in 1999.] Report, ekokött. $18 \mathrm{pp}$.

Appleby, M.C., Hughes, B.O., 1991. Welfare of laying hens in cages and alternative systems: environmental physical and behavioural aspects. World's Poult. Sci. J. 47, 109-128.

Barger, I.A., 1997. Control by management. Vet. Parasitol. 72, $493-500$.

Beck-Friis, J., 2002. Varför inte ta steget full ut KRAV? [Why not go all the way KRAV?] Editorial. Sven. Veterinärtidn. 54, 347.

Bilcik, B., Keeling, L.J., 1999. Changes in feather condition in relation to feather pecking and aggressive behaviour in laying hens. Br. Poult. Sci. 40, 444-451.

Boehncke, E., 1997. Preventive strategies as a health resource for organic farming. In: Isart, J., Llerena, J.J. (Eds.), Resource Use in Organic Farming Proceedings, 3rd ENOF Workshop Ancona Italy June 5-6, pp. 25-35.

Broom, D.M., 1991. Animal welfare: concepts and measurement. J. Anim. Sci. 69, 4167-4175. 
Callicott, J.B., 1989. In Defense of the Land Ethic. State University of New York Press, Albany, NY.

Carstensen, L., Vaarst, M., Roepstorff, A., 2002. Helminth infections in Danish organic swine herds. Vet. Parasitol. 106, $253-264$.

Council Regulation, 1999. Council Regulation (EC) No 1804/1999 of 19 July 1999 supplementing Regulation (EEC) No 2092/91 on organic production of agricultural products and indications referring thereto on agricultural products and foodstuffs to include livestock production. Official Journal L 222 24/08/ 1999, 0001-0028.

Danish Ethical Council concerning Animals, 1995. Udtalelse om økologisk husdyrproduktion [Statement regarding organic livestock production]. Det dyreetiske råd, Ministry of Justice, Copenhagen, Denmark.

Danish Ministry of Food Agriculture and Fisheries, 1999. Action plan II Developments in organic farming, English summary. Danish Directorate for Development, Copenhagen (http:// www.dffe.dk/in_english/index.htm).

DARCOF, 2000. Principles of organic farming. Discussion document prepared for DARCOF Users Committee November 2000 (http://www.foejodk/GB/sider/darcof/discuss/Princip.pdf).

Dawkins, M.S., 1988. Behavioural deprivation: a central problem in animal welfare. Appl. Anim. Behav. Sci. 20, 209-225.

de Jonge, F.H., Bokkers, E.A.M., Schouten, W.G.P., Helmond, F.A., 1996. Rearing piglets in a poor environment: developmental aspects of social stress in pigs. Physiol. Behav. 60, 389-396.

de Passillé, A.M., 2001. Sucking motivation and related problems in calves. Appl. Anim. Behav. Sci. 72, 175-187.

Dimander, S.O., Höglund, J., Spörndly, E., Waller, P.J., 2000. The impact of internal parasites on the productivity of young cattle organically reared on semi-natural pastures in Sweden. Vet. Parasitol. 90, 271-284.

Duncan, I.J.H., 1993. Welfare is to do with what animals feel. J. Agric. Environ. Ethics 6 (Suppl. 2), 8-14.

Egri, C.P., 1999. Attitudes backgrounds and information preferences of Canadian organic and conventional farmers: implications for organic farming advocacy and extension. J. Sustain. Agric. 13, $45-72$.

FAWC, 2001. Interim Report on the Animal Welfare Implications of Farm Assurance Schemes. Farm Animal Welfare Council, London, UK. To be found at: http://www.fawc.org.uk/pdf/ farmassurance.pdf.

Faye, B., Waltner-Toews, D., McDermott, J., 1999. From "ecopathology" to "agroecosystem health". Prev. Vet. Med. 39, $111-128$.

Fraser, D., Weary, D.M., Pajor, E.A., Milligan, B.N., 1997. A scientific concept of animal welfare that reflects ethical concerns. Anim. Welf. 6, 187-205.

Gray, G.D., 1997. The use of genetically resistant sheep to control nematode parasitism. Vet. Parasitol. 72, 345-366.

Hamilton, C., Hansson, I., Ekman, T., Emanuelson, U., Forslund, K., 2002. Health of cows calves and young stock on 26 organic dairy herds in Sweden. Vet. Rec. 150, 503-508.

Hammarberg, K.-E., 2001. Animal welfare in relation to standards in organic farming. Acta Vet. Scand., Suppl. 95, 17-25.
Hansson, I., Hamilton, C., Ekman, T., Forslund, K., 2000. Carcass quality in certified organic production compared with conventional livestock production. J. Vet. Med., B 47, 111-120.

Hardeng, F., Edge, V.L., 2001. Mastitis ketosis and milk fever in 31 organic and 93 conventional Norwegian dairy herds. J. Dairy Sci. 84, 2673-2679.

Hargrove, E.C. (Ed.), 1992. The Animal Rights/Environmental Ethics Debate. State University of New York Press, Albany, NY, USA.

Harper, G.C., Henson, S.J., 2001. Consumer Concerns About Animal Welfare and the Impact on Food Choice-The Final Report. EU FAIR CT98 3678. The University of Reading, Reading, UK.

Heuer, O.E., Pedersen, K., Andersen, J.S., Madsen, M., 2001. Prevalence of thermophilic Campylobacter and antimicrobial susceptibility patterns of zoonotic and indicator bacteria from organic and conventional broilers in Denmark. Paper presented at NKVet Symposium on Veterinary Challenges in Organic Farming. Hverdagerði, Iceland 5-8 Oct. 2000.

Höglund, J., Svensson, C., Hessle, A., 2001. A field survey of the status of internal parasites in calves on organic dairy farms in south western Sweden. Vet. Parasitol. 99, 113-128.

Holmberg, H.-E., 1999. Konsumentundersökning om ekologisk produktion/KRAV [Consumer survey on organic production/ KRAV]. LUI ref number 30-7866, published 1999-12-21 (http://www.krav.se/arkiv/rapporter/luiund.pdf).

Hovi, M., Sundrum, A., Thamsborg, S., 2003. Animal health and welfare in organic livestock production in Europe - current state and future challenges. Livest. Prod. Sci. 80, 41-53.

Hugoson, G., Wallén, C. (Eds.), 2000. Proceedings of the Symposium on Antibiotic Resistance with Emphasis on Animal-Human Transfer, Acta Vet. Scand., Suppl., vol. 93. Acta Veterinaria Scandinavica, Falkenberg, Sweden.

IFOAM, 2000. IFOAM Basic Standards. International Federation of Organic Movements, Tholey-Theley, Germany.

IFOAM, 2002. IFOAM Norms. II. IFOAM Basic Standards for organic production and processing. International Federation of Organic Movements, Tholey-Theley, Germany (http://www. ifoam.org/standard/norms/ibs.pdf).

Jensen, P., 1999. Animal welfare and ecological farming — are they always compatible? Proceedings NJF XXI Congress, Ås, Norway, Nordisk jordbrugsforskning, vol. 81, pp. 232.

Johnsen, P.F., Vestergaard, K.S., Norgaard-Nielsen, G., 1998. Influence of early rearing conditions on the development of feather pecking and cannibalism in domestic fowl. Appl. Anim. Behav. Sci. 60, 25-41.

Kaltoft, P., 1997. Naturetik som praksisbegrep. En undersøgelse af naturforståelse praksis og viden i økologisk jordbrug [Nature ethics as a practical concept. A study of the understanding of nature practices and knowledge in organic farming]. Skriftserie No 5, Department of Technology and Social Sciences. Technical University of Denmark Copenhagen, Denmark. Dissertation.

Kugelberg, C., Johansson, G., Sjögren, U., Bornsten, S., Wallgren, P., 2001. Infektionssjukdomar och ektoparasiter hos slaktsvinhälsoläget hos utomhusgrisar (Infectious diseases and ectoparasites in fattening pigs - the health situation in outdoor pigs). Sven. Veterinärtidn. 53, 197-204. 
Leopold, A., 1949. A Sand County Almanac. Oxford University Press, London, UK.

Lindqvist, Å., Ljungström, B., Nilsson, O., Waller, P.J., 2001. The dynamics prevalence and impact of nematode parasite infections in organically raised sheep in Sweden. Acta Vet. Scand. 42, $377-389$.

Lockeretz, W., Lund, V., 2003. Organic standards: by whom and for whom? In: Hovi, M., Martini, A., Padel, S. (Eds.), SocioEconomic Aspects of Animal Health and Food Safety in Organic Farming Systems Proceedings, 1st SAFO Workshop, September 5-7, Florence, Italy. University of Reading, pp. $201-210$.

Lund, V., 2002. Ethics and animal welfare in organic animal husbandry - an interdisciplinary approach. Acta Univ Agric Suec., Vet., 137. Dept of Animal Environment and Health, Swedish Univ. of Agr. Sci., Skara, Sweden. Doctoral thesis.

Lund, V., Algers, B., 2003. Research on animal health and welfare in organic farming - a literature review. Livest. Prod. Sci. 80, 55-68.

Lund, V., Röcklinsberg, H., 2001. Outlining a conception of animal welfare for organic farming systems. J. Agric. Environ. Ethics $14,391-424$.

Lund, V., Hemlin, S., Lockeretz, W., 2002. Organic livestock production as viewed by Swedish farmers and organic initiators. Agric. Human Values 19, 255-268.

Lund, V., Anthony, R., Röcklinsberg, H., 2004a. The ethical contract as a tool in organic animal husbandry. J. Agric. Environ. Ethics 17, 23-49.

Lund, V., Hemlin, S., White, J., 2004b. Ethics and natural behaviour-Swedish organic farmers' view on animal issues. J. Agric. Environ. Ethics, 157-179.

McCracken, D.I., 1993. The potential for avermectins to affect wildlife. Vet. Parasitol. 48, 273-280.

McGlone, J.J., 1993. What is animal welfare? J. Agric. Environ. Ethics 6 (Suppl. 2), 26-36.

Meyer-Abich, K.M., 1997. Praktische Naturphilosophie Erinnerungen an einen vergessenen Traum. C.H. Beck, München, Germany.

Midgley, M., 1983. Animals and Why They Matter. University of Georgia Press, Athens, GA. 158 pp.

NAHWOA, 2002. Final report. Report to the European Union. To be found at: http://www.veeru.reading.ac.uk/organic.

Næss, A., 1985. Identification as a source of deep ecological attitudes. In: Tobias, M. (Ed.), Deep Ecology. Avanti Books, San Diego, USA.

Næss, A., 1989. Ecology Community and Lifestyle. Cambridge University Press, Cambridge, UK.

Niezen, J.H., Charleston, W.A.G., Hodgson, J., Mackay, A.D., Leathwick, D.M., 1996. Controlling internal parasites in grazing ruminants without recourse to anthelmintics: approaches experiences and prospects. Int. J. Parasitol. 26, 983-992.

Niggli, U., Lockeretz, W., 1996. Development of research in organic agriculture. In: Østergaard, T.V. (Ed.), Fundamentals of Organic Agriculture Proceedings. Volume 1, 11th IFOAM International Scientific Conference 11-15 August, Copenhagen, Denmark, pp. 9-23.
Permin, A., Bisgaard, M., Fransen, F., Pearman, M., Nansen, P., Kold, J., 1999. The prevalence of gastrointestinal helminths in different poultry production systems. Br. Poult. Sci. 40, 439-443.

Roderick, S., Hovi, M., 1999. Animal health and welfare in organic livestock systems: identification of constraints and priorities. Report to the Ministry of Agriculture Fisheries and Food (MAFF). VEERU Department of Agriculture, University of Reading, Reading, UK.

Rollin, B.E., 1993. Animal welfare science and value. J. Agric. Environ. Ethics 6 (Suppl. 2), 44-50.

Rolston III, H., 1988. Environmental ethics. Duties to and Values in the Natural WorldTemple University Press, Philadelphia, USA.

Singer, P., 1981. The Expanding Circle: Ethics and Sociobiology. Farrar Straus and Giroux, New York, USA.

Sörlin, S., 1991. Naturkontraktet. Om naturumgängets historiaCarlssons, Stockholm.

SOU, 1997. Antimicrobial feed additives. Report from the Commission on Antimicrobial Feed Additives. Government official reports, Ministry of Agriculture Stockholm, SOU:132.

Stenmark, M., 2000. Miljöetik och miljövård (Environmental Ethics and Policy Making). Studentlitteratur, Lund, Sweden.

Stenmark, M., 2002. Environmental Ethics and Policy Making. Ashgate, Aldershot.

Strong, L., 1993. Overview: the impact of avermectins on pastureland ecology. Vet. Parasitol. 48, 3-17.

Sundrum, A., 2001. Organic livestock farming. A critical review. Livest. Prod. Sci. 67, 207-215.

Svensson, C., Hessle, A., Höglund, J., 2000. Parasite control methods in organic and conventional dairy herds in Sweden. Livest. Prod. Sci. 66, 57-59.

Szatek, A., 2001. Vägen till marknaden. Kvantitativ undersökning bland allmänheten. Slutrapport. Internal report for Swedish Farmers' Association (LRF), LUI Marknadsinformation AB, Stockholm, Sweden (http://www.ekolantbruk.se).

Taylor, P.W., 1981. The ethics of respect for nature. Environ. Ethics 3, 197-218.

Te Velde, H., Aarts, N., van Workum, C., 2002. Dealing with ambivalence: farmers' and consumers' perceptions of animal welfare in livestock breeding. J. Agric. Environ. Ethics 15, 203-219.

Thamsborg, S.M., Roepsdorff, A., Larsen, M., 1999. Integrated and biological control of parasites in organic and conventional production systems. Vet. Parasitol. 84, 169-186.

Toledo, P., Andrén, A., Björck, L., 2002. Composition of raw milk from sustainable production systems. Int. Dairy J. 12, 75-80.

Vaarst, M., Bennedsgaard, T.W., 2001. Reduced medication in organic farming with emphasis on organic dairy production. Acta Vet. Scand. 42:4 (Suppl. 95), 51-57.

Vaarst, M., Alban, L., Mogensen, L., Thamsborg, S.M., Kristensen, E.S., 2001. Health and welfare in Danish dairy cattle in the transition to organic production: problems, priorities and perspectives. J. Agric. Environ. Ethics 14, 367-390.

Verhoog, H., Matze, M., Lammerts van Bueren, E., Baars, T., 2003. The role of the concept of the natural (naturalness) in organic farming. J. Agric. Environ. Ethics 16, $22-49$.

Verhoog, H., Lund, V., Alrøe, H., 2004. Animal welfare, ethics and organic farming. In: Vaarst, M., Roderick, R., Lund, V., 
Lockeretz, W. (Eds.), Animal Health and Welfare in Organic Agriculture. CABI Publishing, Wallingford, Oxon, UK, pp. 73-94.

Waller, P.J., 1997. Anthelmintic resistance. Vet. Parasitol. 72, $391-412$.

Waller, P.J., 1999. International approaches to the concept of integrated control of nematode parasites of livestock. Int. J. Parasitol. $29,155-164$.

Webster, J., Saville, C., Welchman, D., 1986. Improved Husbandry Systems for Veal Calves. Farm Animal Care Trust, London, UK.
Wechsler, B., Huber-Eicher, B., 1998. The effect of foraging material and perch height on feather pecking and feather damage in laying hens. Appl. Anim. Behav. Sci. 58, 131-141.

Weller, R.F., Bowling, P.J., 2000. Health status of dairy herds in organic farming. Vet. Rec. 146, 80-81.

Wemesfelder, F., Birke, L., 1997. Environmental challenge. In: Appleby, C., Hughes, B.O. (Eds.), Animal Welfare. CAB International, Wallingford, pp. 35-48. 